\title{
Roles of Political and Economic Environments on Agricultural Commodity Import Demand in Developing Economy: A Case Study of Rice Sub-Sector in Nigeria
}

\author{
Sunday B. Akpan ${ }^{1}$, Glory E. Emmanuel ${ }^{2} \&$ Inimfon V. Patrick $^{1}$ \\ ${ }^{1}$ Department of Agricultural Economics and Extension, Akwa Ibom State University, Nigeria \\ ${ }^{2}$ Department of Agricultural Economics and Extension, University of Uyo, Nigeria \\ Correspondence: Sunday B. Akpan, Department of Agricultural Economics and Extension, Faculty of \\ Agriculture, Akwa Ibom State University, Nigeria. E-mail: brownsonakpan10@gmail.com
}

Received: September 14, 2015

Accepted: November 11, 2015

Online Published: November 25, 2015

doi:10.5539/ijef.v7n12p84

URL: http://dx.doi.org/10.5539/ijef.v7n12p84

\begin{abstract}
Nigeria is currently the largest importer of milled rice in the world. The country has implemented several trade policies, set up institutions and incentives to boost domestic production with the intention to meet both domestic and international demands. Despite these attempts and favorable climatic, manpower and edaphic conditions in the country, Nigeria still spent millions of dollars on annual basis on rice imports. Based on this assertion, the study rather examined the roles of political and economic environments on rice import demand from 1960 to 2014 in Nigeria. Time series data were obtained from FAO, Central Bank of Nigeria and National Bureau of Statistics as well as World Bank. Augmented Dickey-Fuller-GLS unit root test showed that all series were integrated of order one. The long-run and short-run elasticity of rice import demand were determined using the techniques of co-integration and error correction models. The trend in rice import revealed that, the country had witnessed significant average positive exponential growth rate of about $15.975 \%$ in rice import from 1960 to 2014. The empirical results revealed that, the long run import demand function of rice responded negatively to the world price, industrial capacity utilization, nominal exchange rate, and the value of gross domestic production; whereas, it reacted positively to period of civilian rule, nominal value of external reserve, period of liberalization and the net volume of credit to the entire economy. The symmetric adjustment coefficient of rice import demand to a long run equilibrium stood at $39.65 \%$ per annum. In the short run, rice import had a significant negative and elastic relationship with the domestic and world price of rice; while it has significant positive inelastic association with external reserve and net credit to the economy. Based on these results; it is recommended that, the Nigeria government should designed programmes and incentives to boost industrial capacity utilization in the country. Markets determine nominal exchange rate should prevail in the economy. The country should regulate its foreign reserve policy by setting a threshold, above which excess deposit should be plough back to the domestic economy inform of investments rather than support excessive importation.
\end{abstract}

Keywords: rice import, macroeconomics, agriculture, rice policies, Nigeria, economy

\section{Introduction}

Rice has remained one of the most important cereals and staple food stuffs in Nigeria (Akpan et al., 2014; and Erhabor \& Ojogho, 2011). Government has enunciated several policies and programmes to boost the domestic production of rice. For instance several tariff regimes has been developed to discourage rice import in addition to quantity restrictions as well as outright banned on import. Government has also collaborated with international institutions and set up research linkages as well as provision of fundamental infrastructures in a bit to give the sub sector a first class lift. Other incentives available in the country are sufficient and affordable arable lands for both paddy and upland rice cultivation with large expand of irrigation waters to support all year round production. Furthermore, Nigeria has the highest demand force for rice in Africa, hence effective demand with respect to rice is not an issue in the country (Cadoni \& Angelucci, 2013; Obaniyi et al., 2014). Despite these lofty incentives and safety nets provided by the federal government, rice import has continuously increased in recent years in Nigeria. The country is acclaimed largest importer of rice in the world. The annual demand for rice in the country is estimated at 5 million tons, while production level is 3 million tons of milled rice resulting in a 
deficit of 2 million tons. To meet the domestic demand, the country had over the years resorted to imports. For instance the Federal Government spent $\$ 2.41$ billion on rice importation between January 2012 and May 2015 (Central Bank of Nigeria, 2015). Between 2010 and 2014, Nigeria imported about 10,876,148.3 tonnes of rice. This has a huge financial implication on the economy and the development of the domestic potentials in the sub-sector.

Although, in recent years, the sub sector has thrived to increase production relative to other West African countries, but the supply gap is still mounting (Aker et al., 2011). Following the dismay performance of the rice sector amidst comfortable trade and institutional policies, there is an overwhelming need to assess the problem of the sub sector through another direction. Issues related to political stability and macroeconomic volatility is pertinent. Akpan (2012) postulated that, macroeconomic and political environments can influence agricultural sector in a positive or negative way. Based on this assertion, the study sought to investigate the effect of macroeconomic fluctuations and political stability on rice import demand in Nigeria. Hence, primarily, the study estimated import demand function of rice in Nigeria.

\section{Literature Review}

Few empirical works have delved into rice import demand function in Nigeria. For instance, Nkang et al. (2006) estimated the determinants of rice import demand in Nigeria using a dynamic regression model. The results show that, the short-run changes in domestic rice production, level of external reserves and total import value remarkably shaped rice import behaviour in Nigeria. Also, Ogundele (2007) examined the effects of various trade policy instruments such as tariff, import restrictions, outright ban on rice import and other determinants on the import demand for rice in Nigeria between 1960 and 2007. The long run equilibrium model revealed that, exchange rate, per capita income and local output of rice have positive significant relationships with rice import demand. The short run dynamic model (ECM) result further confirmed the significance of per capita income and local output as major positive determinants of rice import in Nigeria. In another empirical work, Lançon and Hélène (2007) posited that, policy measures are among the major determinant of expansion of rice imports in developing countries. Chimobi and Ogbonna (2008) investigated the behaviour of Nigeria's aggregate imports between the periods 1980-2005 using cointegration and error correction approach. The result suggests that, real GDP largely explains the import demand function in Nigeria. Igberi et al. (2012) analyzed import and export elasticity of agricultural products in Nigeria. They discovered that, gross domestic product, external reserve and liberalization dummy were positively signed and statistically significant at $1 \%$ level. Aziz (2013) studied aggregate import demand function for developing countries. He found the real income and relative price of import as well as foreign exchange reserves as major significant determinants of import demand for developing countries.

From the empirical literature reviewed, it is evidenced that political environment has not been considered in the rice demand function in developing countries. This is a serious missing linked especially in Nigeria, where politic plays a significant role in economic activities. Also, some of the studies stick to the traditional theoretical framework of import demand by incorporating few macroeconomic variables in the function. This study bridges that gap by expanding macroeconomic variables in the function and also incorporating political stability dummy in the model.

\section{Theoretical Framework}

Following the work of Mayes (1981), a simple import demand function is explicitly shown as:

$$
M_{t}=\vartheta Y^{\alpha}\left(\frac{P_{m}}{P_{d}}\right)^{\beta}
$$

Where $\mathrm{M}=$ Import, $\mathrm{Y}=$ Domestic income, $\mathrm{Pm}=$ international price of commodity of $\mathrm{i}, \mathrm{Pd}=$ domestic price of commodity i. Attaching log to equation 1 will yield:

$$
\log \left(M_{t}\right)=\log \left(\vartheta Y^{\alpha}\left(\frac{P_{m}}{P_{d}}\right)^{\beta}\right)
$$

Linearizing equation 2 and expressing it explicitly will yield:

$$
\log \left(M_{t}\right)=\log \vartheta+\alpha \log (Y)+\beta \log \left(\frac{P_{m}}{P_{d}}\right)+\mu_{t}
$$

Where $\alpha$ and $\beta$ are import elasticity of demand with respect to domestic income and own price of commodity. However, equation 3 has been expanded to include several explanatory variables such as exchange rate, per capita 
income; external reserve and liberalization dummy etc. (Ogundele, 2007; Igberi et al., 2012; and Aziz, 2013). The study further expands equation 3 by including dummies.

\section{Methodology}

\subsection{Research Methodology}

\subsubsection{Study Area}

The study was conducted in Nigeria; the country is situated on the Gulf of Guinea in the sub Saharan Africa. Nigeria lies between $4^{0}$ and $14^{\circ}$ North of the Equator and between longitude $3^{\circ}$ and $15^{\circ}$ East of the Greenwich. The country has a total land area of about $923,769 \mathrm{~km}^{2}$ (or about 98.3 million hectares) with $853 \mathrm{~km}$ of coastline along the northern edge of the Gulf of Guinea and a population of over 140 million people (NPC, 2006). Nigeria is bounded by the Republics of Benin in the west, Chad and Cameroon in the east and Niger to the north.

\subsubsection{Data Source}

Secondary data were used for the study. These data were sourced from several publications of Central Bank of Nigeria (CBN), National Bureau of Statistics, Food and Agricultural Organization (FAO) as well as the World Bank. Data covered the period from 1960 to 2014.

\subsection{Analytical Technique}

\subsubsection{The Trend Analysis of Rice Import in Nigeria (1960-2014)}

The study investigated the nature of movement and growth rate in rice import in Nigeria. An exponential trend equation was specified as thus:

$$
\log _{e} Q R I_{t}=b_{0}+b_{1} T+U_{t}
$$

Where ' $\mathrm{T}$ ' is the time expressed in year; $\mathrm{QRI}$ is the annual quantity of rice import (tons) in Nigeria. The exponential growth rate is given as:

$$
(r)=\left(e^{b 1}-1\right) * 100
$$

To ascertain whether the growth rate in the rice import assumes an accelerated or decelerated rate over increased period of time, the quadratic exponential trend equation was specified as thus:

$$
\log _{e} P_{t}=b_{o}+b_{1} t_{1}+b_{2} t_{2}^{2}+u_{t}
$$

If $b_{2}>0$; the index investigated had accelerated positive or negative growth rate: when $b_{2}<0$; the growth rate is not significant.

\subsubsection{Long Run Rice Import Demand Function in Nigeria}

To determine the long run rice import demand function for the sub sector, a time dependent regression model was specified at the level of variables. The model is specified explicitly as thus:

$$
O R I_{t}=\beta_{0}+\beta_{1} G D P_{t}+\beta_{2} E X C_{t}+\beta_{3} I C U_{t}+\beta_{4} C A S_{t}+\beta_{5} E X R_{t}+\beta_{6} P O L_{t}+\beta_{7} P P R+\beta_{8} P R W_{t}+\beta_{9} L I B_{t}+\mu_{t}
$$

Where;

$\mathrm{QRI}_{\mathrm{t}}=$ Quantity of rice import in time ' $\mathrm{t}$ ' (tons);

$\mathrm{GDP}_{\mathrm{t}}=$ Annual GDP of Nigeria at current purchaser price $(\mathrm{N})$;

$\mathrm{EXC}_{\mathrm{t}}=$ Nominal exchange rate of Naira for Dollar;

$\mathrm{ICU}_{\mathrm{t}}=$ Annual industrial capacity Utilization as a proxy of Domestic Utilization (\%);

$\mathrm{CREt}=$ Net Domestic credit to the Nigeria economy as incentive to domestic production $(\mathbb{N})$;

$\mathrm{EXR}_{\mathrm{t}}=$ Annual volume of external reserve as enhancement of importation ( $($ );

POLt $=$ Political stability Dummy (1 during democratic era and 0 during military period);

$\mathrm{PPRt}=$ Producer price of rice in Nigeria as a proxy of substitute price $(\mathrm{N} / \mathrm{ton})$;

$\mathrm{PRWt}=$ Producer price of rice at international market (world price/domestic price);

$\mathrm{LIBt}=$ Liberalization effect on international trade (1 from 1986 to 2014 and 0 otherwise);

$\mathrm{U}_{\mathrm{t}}=$ Stochastic error term and $U_{t} \sim \operatorname{IID}\left(0, \delta_{\mathrm{U}}^{2}\right) . \beta$ 's are long run import elasticity.

To validate the existence of the long run stable relationship in the rice import function in Nigeria, the study applied the Engle and Granger two-step technique and Johansen co-integration test. Following the Granger Representation Theorem, the Error Correction Model (ECM) for the co-integrating series in the study was specified. This model 
represents the short run import function for rice in Nigeria. The general specification of the error correction Model specified for the rice import function in Nigeria is explicitly shown below:

$$
\Delta \mathrm{LnQRI}_{t}=\varphi_{0}+\varphi_{1} \sum_{i=1}^{n} \Delta \operatorname{LnQRI_{t-1}}+\varphi_{2} \sum_{i=1}^{n} \Delta \operatorname{LnX}_{t-i}+\varphi_{3} E C M_{t-1}+U_{t}
$$

Variables are as defined previously in equation 7; and coefficients $\left(\varphi_{3}\right)$ of the $\operatorname{ECM}_{t}\left(-1<\boldsymbol{\beta}_{3}<0\right)$ measures the deviation from the long-run equilibrium in period $\left({ }_{t-1}\right)$.

\subsection{Augmented Dickey-Fuller (ADF)-GLS Test}

Stationary of time series is needed to avoid the incidence of spurious regression. It is therefore necessary to convert non- stationary series to stationary status in order to obtain reliable regression estimates. In estimating an Error Correction Model, this study applies the Augmented Dickey- Fuller (ADF) - GLS test to examine the stationary characteristics of the series. As suggested by Dickey and Fuller (1981), equation (9) is used to test the stationary of specified variables.

$$
\Delta y_{t}=\mu_{t}+\alpha_{2} y_{t-1}+\sum_{i=1}^{k} \beta_{i} \Delta y_{t-i}+\varepsilon_{t}
$$

Where ' $\mathrm{y}$ ' represents the variables to be tested, $\Delta$ represents the first difference operator; $t$ is the time drift; $k$ represents the number of lags used and $\varepsilon$ is the error term, which is assumed to be normally and identically distributed with constant means and variance;' $\alpha$ and $\delta$ are the model bounds. It is a one-sided test whose null hypothesis is $\alpha_{2}=0$ versus the alternative $\alpha_{2}<0$. Following the work of Elliott, Rothenberg and Stock (1996), ADF-GLS unit root involves estimating the standard ADF test equation after substituting the Generalized Least Squares detrended $y_{t}^{d}$ for the original $y_{t}$ as shown in equation (10). The test variant offers greater power than the regular ADF test.

\section{Results and Discussion}

$$
\Delta y_{t}^{d}=\alpha_{2} y_{t}^{d}+\sum_{i=1}^{k} \beta y_{t-1}^{d}+V_{t}
$$

The descriptive statistics of raw variables used in the study is shown in Table 1 . The result revealed high degree of volatility among specified variables. GDP and CRE exhibited the highest level of variability. However, variability was low in ICU and PRW.

Table 1. Summary statistics, of variables used in the analysis

\begin{tabular}{lcccccccc}
\hline \multicolumn{1}{c}{ Variable } & Mean & Median & Min. & Max. & Std. Dev. & C.V. & Skewness & Ex. kurtosis \\
\hline QRI & $6.04 \mathrm{e}+5$ & 356135 & 255.000 & $2.29 \mathrm{e}+6$ & 673274 & 1.114 & 1.219 & 0.495 \\
PPR & 27074 & 1415 & 100.000 & 144600 & 44588.9 & 1.647 & 1.502 & 0.743 \\
PRW & 0.929 & 0.809 & 0.339 & 1.929 & 0.431 & 0.463 & 0.496 & -0.994 \\
POL & 0.509 & 1.000 & 0.000 & 1.000 & 0.504 & 0.991 & -0.036 & -1.998 \\
EXR & $1.22 \mathrm{e}+12$ & $5.81 \mathrm{e}+9$ & $8.03 \mathrm{e}+7$ & $7.49 \mathrm{e}+12$ & $2.33 \mathrm{e}+12$ & 1.905 & 1.674 & 1.092 \\
ICU & 52.763 & 54.800 & 29.290 & 78.700 & 13.977 & 0.265 & 0.082 & -1.121 \\
EXC & 42.242 & 4.018 & 0.546 & 158.550 & 59.745 & 1.414 & 0.985 & -0.845 \\
GDP & $4.12 \mathrm{e}+13$ & $1.12 \mathrm{e}+11$ & $2.99 \mathrm{e}+9$ & $8.90 \mathrm{e}+14$ & $1.45 \mathrm{e}+14$ & 3.527 & 4.422 & 20.663 \\
LIB & 0.527 & 1.000 & 0.000 & 1.000 & 0.504 & 0.956 & -0.109 & -1.988 \\
CRE & $2.01 \mathrm{e}+12$ & $4.03 \mathrm{e}+10$ & $5.35 \mathrm{e}+7$ & $2.09 \mathrm{e}+13$ & $4.79 \mathrm{e}+12$ & 2.382 & 2.681 & 6.147 \\
\hline
\end{tabular}

Source: Computed by authors. Variables are as defined in equation 4 .

\subsection{Unit Root Test of Variables Used in the Analysis}

To ascertain the stationary of variables used in the study, the standard Augmented Dickey-Fuller GLS test for unit root was performed. Test statistic for each variable in level and first difference involving trend and without trend ADF-GLS equations are presented in Table 2. The ADF-GLS test result reveals that, at level all specified variables were non stationary, but were stationary at first difference. 
Table 2. Result of the unit root test for variables used in the analysis

\begin{tabular}{|c|c|c|c|c|c|c|c|c|}
\hline \multirow{3}{*}{ Variable } & \multirow[b]{3}{*}{ Lag } & \multicolumn{7}{|c|}{ ADF-GLS Unit Root Test } \\
\hline & & \multicolumn{3}{|c|}{ With Constant } & \multicolumn{4}{|c|}{ With Constant and Trend } \\
\hline & & Level & $1^{\text {st }}$ Diff. & OT & Lag & Level & $1^{\text {st }}$ Diff. & OT \\
\hline QRI & 0 & -0.424 & $-10.078 * * *$ & $1(1)$ & 0 & -2.029 & $-10.571 * * *$ & $1(1)$ \\
\hline PPR & 0 & 1.579 & $-7.726 * * *$ & $1(1)$ & 0 & -1.665 & $-7.878 * * *$ & $1(1)$ \\
\hline PRW & 0 & -2.166 & $-7.279 * * *$ & $1(1)$ & 0 & -3.232 & $-7.684 * * *$ & $1(1)$ \\
\hline EXR & 0 & 0.823 & $-6.022 * * *$ & $1(1)$ & 0 & -2.005 & $-6.437 * * *$ & $1(1)$ \\
\hline ICU & 0 & -1.013 & $-4.563 * * *$ & $1(1)$ & 0 & -1.179 & $-4.572 * * *$ & $1(1)$ \\
\hline EXC & 0 & 1.111 & $-5.584 * * *$ & $1(1)$ & 0 & -1.209 & $-5.843^{* * *}$ & $1(1)$ \\
\hline GDP & 0 & 2.111 & $-8.576^{* * *}$ & $1(1)$ & 0 & -2.129 & $-7.623 * * *$ & $1(1)$ \\
\hline CRE & 0 & 1.725 & $-5.686^{* * *}$ & $1(1)$ & 0 & -3.438 & $-6.510 * * *$ & $1(1)$ \\
\hline \multirow[t]{2}{*}{ CV at $1 \%$} & & & & & & -3.584 & -3.584 & \\
\hline & \multicolumn{8}{|c|}{ Test of Residuals from the long run estimates } \\
\hline CV at $1 \%$ & $\mathbf{0}$ & $-4.368 * * *$ & - & $1(0)$ & & $-4.937 * * *$ & - & $1(0)$ \\
\hline
\end{tabular}

Note. OT means order of integration. Critical value (CV) is defined at $1 \%$ significant level and asterisks $* * *$ represents $1 \%$ significance level. Variables are expressed in logarithm and are as defined previously in equation 7.

The critical value was kept at $1 \%$ significant level to ensure the best result. The result of the ADF-GLS unit root test implies that, the analysis of the specified variables at their levels could result in spurious regression estimates. This indicates that, the variables should be tested for the presence of co-integration and Error Correction mechanism (Johansen, 1988; and Johansen \& Juselius, 1990).

\subsection{Result of Trend Analysis of Rice Import Demand in Nigeria}

Estimates of the exponential trend equation for rice import are presented in Table 3 . The result revealed that, rice import in Nigeria has a positive significant relationship with time. This implies that, rice import increases as time increase. An average exponential growth rate of about 15.98\% was obtained in rice import from 1960 to 2014. This means that, rice import demand has continuously witness upsurge over the years under consideration.

Table 3. Exponential trend analysis of rice import in Nigeria

\begin{tabular}{lccc}
\hline \multicolumn{1}{c}{ Variable } & Coefficient & Standard Error & t-value \\
\hline Constant & 7.09652 & 0.396413 & $17.90^{* * *}$ \\
Time & 0.159751 & 0.0123160 & $12.97 * * *$ \\
F- cal. & $168.24 * * *$ & \\
R-square & 0.76045 & \\
Exp. GR (\%) & 15.975 & \\
\hline \multicolumn{1}{c}{ Quadratic trend Equation estimates } & $10.260^{* * * *}$ \\
\hline Constant & 5.18932 & 0.505870 & $8.650^{* * *}$ \\
Time & 0.360508 & 0.0416777 & $-4.969^{* * *}$ \\
Time Square & -0.003585 & 0.000721439 & \\
F- cal. & $134.076^{* * *}$ & & \\
Adjusted R-square & 0.83133 & & \\
\hline
\end{tabular}

Note. Values in bracket represent t-values. The asterisks *** represents $1 \%$ significance level.

Coefficient of the square time in the quadratic trend equation indicates that, there is a significant negative relationship between rice import and square of time in Nigeria. The result showed marginal declined in rice import over doubled increase in time. Decline in rice import over increase time implies that, government policies on increase domestic production of rice gained momentum over increase time. This result revealed the efficacy of the long term policies in rice sub sector in Nigeria. Alternatively, the result means that, the various fiscal, monetary as well as trade policies in addition to incentives implemented by various government regimes in the country to reduce rice import and intensify domestic production marginally and adversely affected rice importation in the long run in the country.

To further substantiate the trend behaviour of rice import in Nigeria, figure 1 shows the linear trend graphs of 
tonnage of rice imported in the country. Rice import in Nigeria was very insignificant in the 1960s and early 1970s as depicted by a steady horizontal line at the trough of the graph. The preference for foreign rice among Nigerian was very low during this period. Import substitute policies were vigorously pursuit by the federal government. Interest of government then was focused on domestic production through government interventions. In this era, agricultural development was embedded in the country development plans.

The period 1975 to 1985 marked an era of oil boom in Nigeria. The country external reserve escalated and there were incentives for importation. During the early period, tariff on rice import stood at $66.6 \%$ in $1974,20 \%$ in 1975 and 10\% in 1978. In 1979 only government license agents were mandated to import rice in the country. Following favorable environment for importation, the country witnessed massive imports of rice as depicted by upward movement in the trend in this period. The ban on rice importation came into effect in 1985. It was anticipated to stimulate domestic production through market determined price of the commodity.

In the period 1986-1995, rice import assumes a low and declining trend. Many analysts attributed the occurrence of this trend to restrictive trade policies and outright banned on rice importation. The ban on rice importation came into effect in 1985. This policy direction was intended to stimulate domestic production through private initiatives and competitive market structure. The introduction of the Structural Adjustment Program (SAP) in 1986 reinforced the ban already placed on rice import (Akande, 2003).

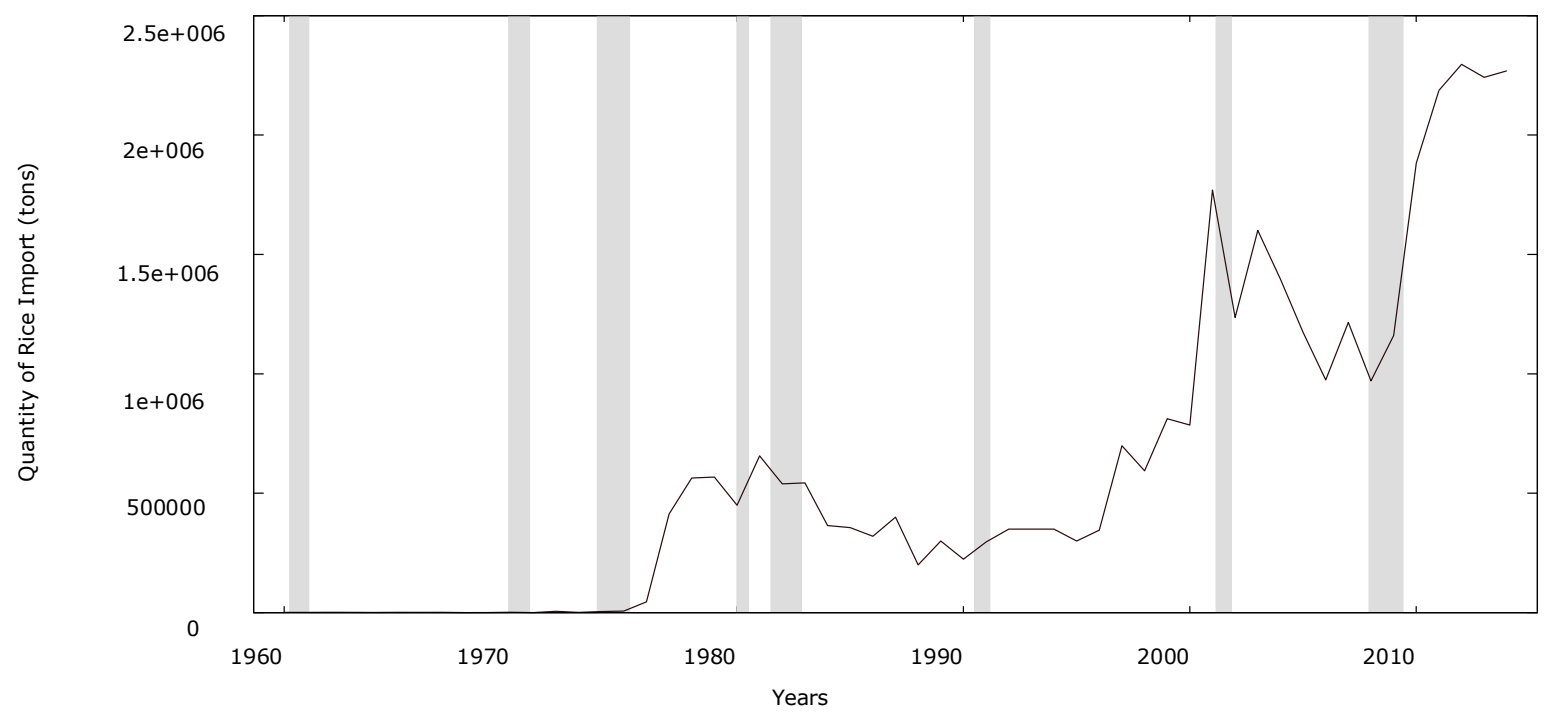

Figure 1. Trend in rice import in Nigeria (1960-2014)

This was in addition to the depreciation of the naira arising from exchange rate deregulation. The overvalued exchange rate had served as an implicit tax on rice producers as it cheapened imported rice relatively (Akande, 2003). Despite the stringent policies on rice trade, significant quantity of imported rice was still found in the Nigeria's markets. Again, economists linked this scenario to the porous nature of the nation borders and issues on corruption (Akande, 2003). Also, during this period, the nation witnessed the highest level of macroeconomic volatility and continuous draining of the external reserves. During this era, importation was economically disabled, while domestic production shrink and this encourages massive smuggling through the boarders. Towards the end of the period, (i.e. 1992), restrictions on rice import were lessen and this encourages gradual inflow of rice imports. In 1995 rice imports were allowed at a $100 \%$ tariff.

The period 1996 to 2002 saw a rebirth in rice importation with lesser restrictions and more favorable tariff regime. Rice import trended upward during this period. In this era, the country economy was liberalized and the quantitative restrictions on rice importation were lifted. In 1996 the tariff was reduced to 50\% and remained at $50 \%$ till 2001 and later came full cycle to $100 \%$ in 2002. Presidential Initiative on increased Rice Production was inaugurated in 2002. The programme was saddled with the responsibility of meeting domestic demand by 2006 and export surpluses in 2007. This programme yielded initial response from increase domestic production. This forces the rice import trend down till 2009. In the period 2009, the Nigerian National Rice Development Strategy (NRDS) was formed. NRDS was mandated to raise paddy output from 3.4 million tonnes in 2007 to 12.8 million tonnes in 2018. In 2011, the Presidential Transformation Agenda was inaugurated to promote private investment 
in rice production in Nigeria. Despite these programmes, rice import continues to grow upward. Hence, the trend in the rice import in Nigeria has been consistence with the various policy regimes in the country. The trend assumes undulated pattern with troughs and crests responding to several policy environments in the country.

\subsection{Co-Integration Test for Rice Import Function in Nigeria}

The study applied the Engle and Granger two-step technique and Johansen cointegration approach to examine the co-integration relationship among specified variables. The result of the Engle and Granger two-step technique of cointegration test is presented in the lower portion of Table 2 . The results showed that at $1 \%$ significance level of critical value, the Engle-Granger cointegration tests reject the null hypothesis of no cointegration. Hence, there exists a long run equilibrium relationship between the rice import and selected macroeconomic variables in Nigeria. The results showed that at $1 \%$ probability level of significance, the Augmented Dicker-Fuller -GLS (ADF-GLS) test for the residuals at level is greater than the critical value at $1 \%$ probability value.

Table 4. Johansen cointegration test results

\begin{tabular}{lcccccc}
\hline (Null) & $\begin{array}{c}\text { Hypotheses } \\
\text { (Alternative) }\end{array}$ & Eigenvalue & $\begin{array}{c}\text { Trace } \\
\text { Statistic }\end{array}$ & $\begin{array}{c}\mathbf{0 . 0 5} \\
\text { Critical Value }\end{array}$ & $\begin{array}{c}\text { Max-Eigen } \\
\text { Statistic }\end{array}$ & $\begin{array}{c}\mathbf{0 . 0 5} \\
\text { Critical Value }\end{array}$ \\
\hline $\mathrm{r}=0$ & $\mathrm{r} \geq 1$ & 0.9808 & $610.8171^{* * *}$ & 239.2354 & $209.5632^{* * *}$ & 64.5047 \\
$\mathrm{r} \leq 1$ & $\mathrm{r} \geq 2$ & 0.8895 & $401.2539^{* * *}$ & 197.3709 & $116.7613^{* * *}$ & 58.4335 \\
$\mathrm{r} \leq 2$ & $\mathrm{r} \geq 3$ & 0.8405 & $284.4926^{* * *}$ & 159.5297 & $97.2773^{* * *}$ & 52.3626 \\
$\mathrm{r} \leq 3$ & $\mathrm{r} \geq 4$ & 0.7936 & $187.2153^{* * *}$ & 125.6154 & $83.6252^{* *}$ & 46.2314 \\
$\mathrm{r} \leq 4$ & $\mathrm{r} \geq 5$ & 0.5657 & $103.5901^{* *}$ & 95.7537 & $44.2108^{* *}$ & 40.0776 \\
$\mathrm{r} \leq 5$ & $\mathrm{r} \geq 6$ & 0.3980 & 59.37924 & 69.8189 & 26.8991 & 33.8769 \\
$\mathrm{r} \leq 6$ & $\mathrm{r} \geq 7$ & 0.2934 & 32.48014 & 47.8561 & 18.4128 & 27.5843 \\
$\mathrm{r} \leq 7$ & $\mathrm{r} \geq 8$ & 0.1459 & 14.06735 & 29.7971 & 8.3635 & 21.1316 \\
$\mathrm{r} \leq 8$ & $\mathrm{r} \geq 9$ & 0.0976 & 5.7039 & 15.4947 & 5.4403 & 14.2646 \\
$\mathrm{r} \leq 9$ & $\mathrm{r} \geq 10$ & 0.0049 & 0.2636 & 3.8415 & 0.2636 & 3.8415 \\
\hline
\end{tabular}

Note. Trace test indicates 12 co-integrating equations at $5 \%$ significant level. * denotes rejection of the null hypothesis at 0.05 level.

**MacKinnon-Haug-Michelis (1999) p-values.

For the Johansen co-integration approach, the tabulated trace and maximum eigenvalue test statistics were significant at various rank levels. The result as presented in Table 4 revealed that the calculated trace test and maximum eigenvalue test statistics are greater than the critical values at various conventional probability levels. This result confirms the presence of cointegration between rice import and some determinants of rice imports in Nigeria. Following the presence of cointegration in the rice import demand function in Nigeria, the long run rice import demand function was estimated and presented in Table 5. The estimated coefficients represent the long run rice import demand elasticity with respect to each specify macroeconomic variable.

Table 5. Long run rice import demand estimates in Nigeria

\begin{tabular}{lccc}
\hline Variables & coefficient & Standard Error & t-test \\
\hline Constant & -17.4795 & 3.52804 & $-4.9544^{* * *}$ \\
PPR & -1.17044 & 0.785933 & -1.4892 \\
PRW & -0.90038 & 0.515846 & $-1.7454^{*}$ \\
POL & 0.818124 & 0.343589 & $2.3811^{* *}$ \\
EXR & 1.07003 & 0.221856 & $4.8231^{* * *}$ \\
ICU & -1.34995 & 0.667176 & $-2.0234^{* *}$ \\
EXC & -1.20899 & 0.502338 & $-2.4067^{* *}$ \\
GDP & -0.46222 & 0.220313 & $-2.0980^{* *}$ \\
LIB & 1.62474 & 0.936633 & $1.7347^{*}$ \\
CRE & 1.27426 & 0.199516 & $6.3868^{* * *}$ \\
\hline \multicolumn{2}{c}{ Diagnostic Tests } & & \\
\hline R- Square & & & \\
F-Cal. & 0.917351 & & \\
LM (autocorrelation) & $55.49670^{* * *}$ & & \\
Normality Test & $5.95178^{* *}$ & & \\
RESET test & $4.95551^{*}$ & & \\
DWatson & $22.7085^{* * *}$ & & \\
\hline
\end{tabular}

Note. Variables are expressed in logarithm. 


\subsection{Stability of the Long Run Rice Demand Function in Nigeria}

Testing the stability of the long run rice import demand function is very important especially when formulating policies to promote trade and domestic production. In testing the model stability, it is observed whether the estimated rice import demand function remain stable within a certain probability over the specified period of time. The study used CUSUM tests and Recursive coefficients to check the rice import demand function. The CUSUM test is based on the cumulative sum of the recursive residuals.

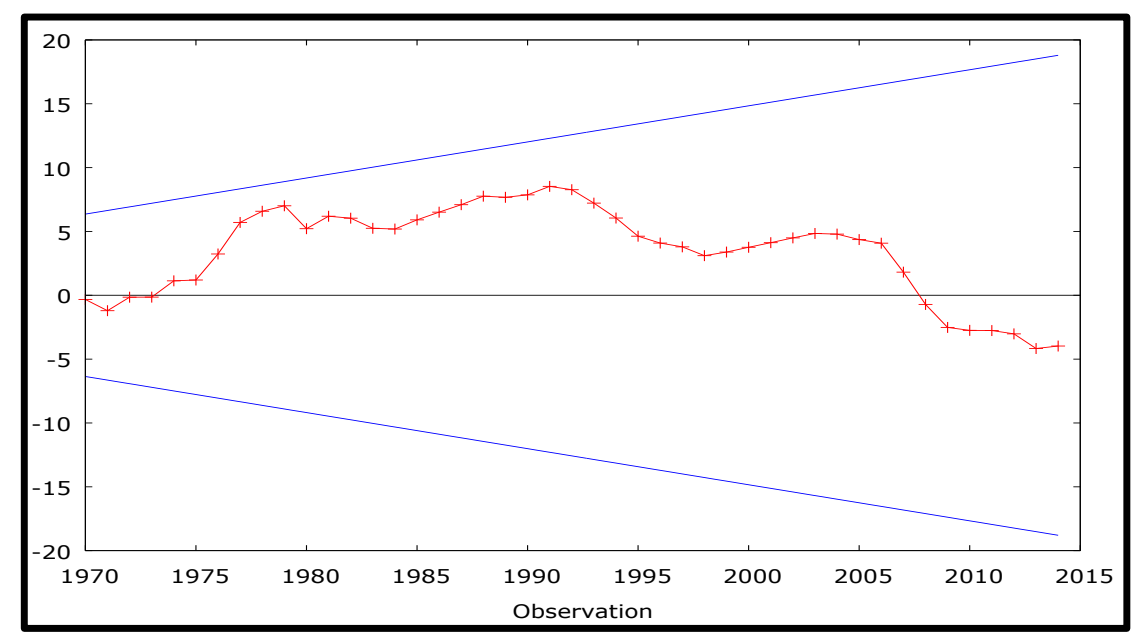

Figure 2. CUSUM plot with $95 \%$ confidence band

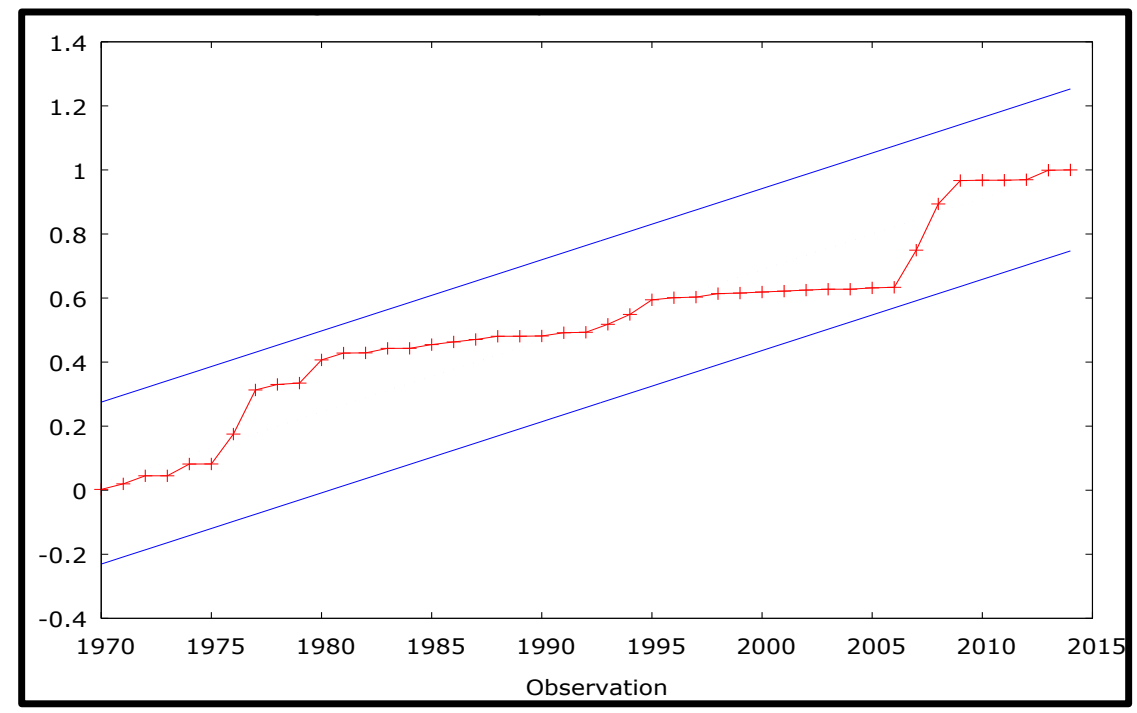

Figure 3. CUSUMSQ plot with 95\% confidence band

Figure 2 and Figure 3 show that the long run rice import demand function is stable during the sample period specified because the cumulative sum revolves between the two critical lines. The CUSUM of Squares Test indicates that residual variance is stable over the sample period because cumulative sum of squares line does not go outside the $5 \%$ critical lines. The result of the stability tests show that all estimated coefficients of the explanatory variables revolve within the two critical bands, so all coefficients estimated in rice imports demand function are stable in the long run.

\subsection{Generating Optimal Lag-Length for the Co-Integrating Variables}

Appropriate lag length for the co-integrating series is needed to generate the error correction model (ECM) for the co-integrating variables. The Akaike criterion (AIC), Schwarz Bayesian criterion (BIC) and Hannan- Quinn criterion (HQC) tests were employed to determine the appropriate lag length. The test result as shown in Table 6 
indicates that the optimum lag length appropriate for generating the ECM is at lag 1.

Table 6. Determination of optimum lag length

\begin{tabular}{lccccc}
\hline Lag & Loglike & P(LR) & AIC & BIC & HQC \\
\hline $\mathbf{1}$ & -686.759 & - & 27.363 & $27.779^{*}$ & $27.522^{*}$ \\
$\mathbf{2}$ & -685.633 & 0.1331 & $27.358^{*}$ & 27.813 & 27.532 \\
$\mathbf{3}$ & -684.892 & 0.223 & 27.368 & 27.861 & 27.556 \\
$\mathbf{4}$ & -684.281 & 0.269 & 27.383 & 27.384 & 27.586 \\
\hline
\end{tabular}

Note. The asterisks below indicate the best (that is, minimized) values of the respective information criteria, AIC $=$ Akaike criterion, BIC $=$ Schwarz Bayesian criterion and HQC = Hannan-Quinn criterion.

\subsection{Error Correction Model for Rice Import in Nigeria}

The primary reason for estimating the ECM model was to capture the dynamics in the rice import and identify the speed of adjustment as a response to departure from the long-run equilibrium. The study adopted Hendry's (1995) approach in which an over parameterized model is initially estimated and then gradually reduced by eliminating insignificant lagged variables until appropriate model is obtained. The result of the exercise is presented in Tables 7. The slope coefficient of the error correction term is negative and statistically significant at $5 \%$ significant level.

Table 7. Short run demand function of rice import in Nigeria

\begin{tabular}{lccc}
\hline Variables & coefficient & Standard Error & t-value \\
\hline Constant & 0.1866 & 0.2860 & 0.653 \\
$\Delta \ln$ QRI $I_{t-1}$ & -0.2017 & 0.2808 & -0.718 \\
$\Delta \ln$ PPR & -1.2071 & 0.5323 & $-2.268^{* *}$ \\
$\Delta \ln$ PRW & -1.1065 & 0.4840 & $-2.286^{* *}$ \\
POL & -0.1289 & 0.1982 & -0.651 \\
$\Delta \ln$ EXR & 0.3516 & 0.1684 & $2.088^{* *}$ \\
$\Delta \ln$ ICU & -0.2191 & 0.9124 & -0.240 \\
$\Delta \ln$ EXC & 0.5363 & 0.3946 & 1.359 \\
$\Delta \ln$ GDP & -0.0664 & 0.0724 & -0.918 \\
LIB & -0.1136 & 0.1926 & -0.589 \\
$\Delta \ln$ CRE & 0.6429 & 0.2238 & $2.873^{* * *}$ \\
ECM & -0.3965 & 0.1526 & $-2.598^{* *}$ \\
\hline & & Diagnostic & Tests \\
\hline R- Square & 0.3884 & F-cal & $1.9716^{*}$ \\
Loglik. & -50.4043 & Normality test & $8.951^{* *}$ \\
DW test & 1.6665 & RESET Test & 0.9337 \\
\hline
\end{tabular}

Note. Variables are expressed in logarithm.

The result validates the existence of a stable long-run symmetric equilibrium relationship in the specified rice import demand function in Nigeria, and also indicates that rice import is sensitive to the departure from its equilibrium value in the previous periods. The slope coefficient of the error correction term (-0.3965) represents the speed of adjustment and also is consistent with the hypothesis of convergence towards the long-run equilibrium once the equilibrium status of rice import demand is disturbed. The stronger the negative value of the ECM, the shorter the period it takes rice import demand to adjust to equilibrium position amidst specified explanatory variables in the long run and vice versa.

The diagnostic test for the ECM model revealed $\mathrm{R}^{2}$ value of 0.3884 . The Durbin-Watson value for the rice import demand equation indicates significant effect of serial correlation. The ECM model has been shown to be robust against residual autocorrelation. Therefore, the presence of autocorrelation does not affect the estimates (Laurenceson \& Chai, 2003). The normality test is significant and this justifies the use of Ordinary Least Squares estimation technique. 


\subsection{Stability of the Short Run Rice Demand Function in Nigeria}

The test result revealed that more that $90 \%$ of the estimates of the short run model are stable at $5 \%$ probability level within the period under consideration. The CUSUM test is based on the cumulative sum of the recursive residuals.

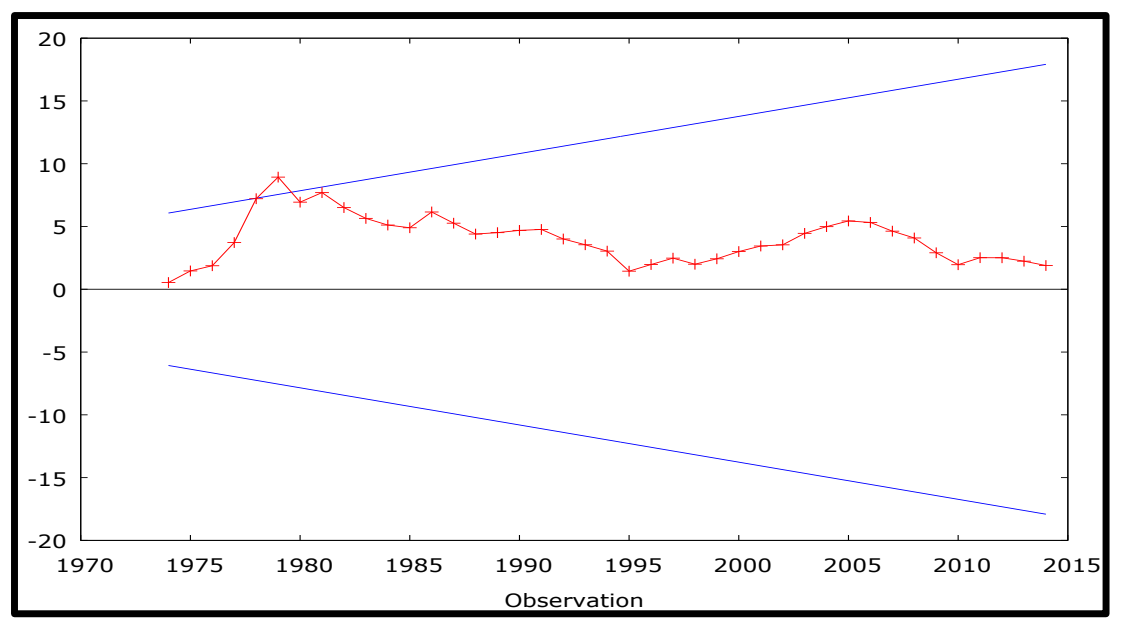

Figure 4. CUSUM plot with 95\% confidence band

\subsection{Result of the Long Run Elasticity of Rice Import Demand Function in Nigeria}

The Long run model results revealed that, rice import has a significant negative and inelastic relationship with respect to the price of rice at international market. This means that, $1 \%$ change in the world price of rice will lead to less than $1 \%$ change in the quantity of rice imported in Nigeria. This implies that, the rate at which world price of rice change is greater than the rate at rice import demand change in Nigeria. The result indicates that, the volume of rice import has a negative causal relationship with the international price of rice. The finding suggests that, rice is a normal good and thus represents a reliable tool for food self- sufficiency of the federal government. This result corroborates with empirical finding of Aziz (2013).

Table 8. Long and short run elasticities of rice import function

\begin{tabular}{lcc}
\hline Variables & Long run Elasticity & Short run Elasticity \\
\hline PPR & -1.17044 & $-1.2071^{* *}$ \\
PRW & $-0.90038^{*}$ & $-1.1065^{* *}$ \\
POL & $0.818124^{* *}$ & -0.1289 \\
EXR & $1.07003^{* * *}$ & $0.3516^{* *}$ \\
ICU & $-1.34995^{* *}$ & -0.2191 \\
EXC & $-1.20899^{* *}$ & 0.5363 \\
GDP & $-0.46222^{* *}$ & -0.0664 \\
LIB & $1.62474 *$ & -0.1136 \\
CRE & $1.27426^{* * *}$ & $0.6429^{* * *}$ \\
\hline
\end{tabular}

Also, rice import has a long run elastic relationship with industrial capacity utilization rate in Nigeria. This means that, $10 \%$ change in rice import demand will be greater than $10 \%$ change in industrial capacity utilization rate in Nigeria. This result suggests that, the domestic industrial sector has some levels of backward integration policies with the agricultural sector in the country. The presence of poor supportive infrastructures and manufacturing policy misalignment could also be useful in explaining the inverse causal relationship in the long run between rice import and capacity utilization of industrial sector in Nigeria. Another possible reason for this result could be explain by the low manufacturing capacity in the country. The manufacturing sector in Nigeria is still at the infancy level; hence the absorptive capacity of the sector cannot sufficiently compete with the continuous inflow of rice import. 
Similarly, the quantity of rice import exhibited inverse and elastic relationship with the nominal exchange rate in the long run in the country. Explicitly, 1 unit change in the nominal exchange rate will result at more than I unit change in rice import demand in Nigeria. This means that, as the exchange rate $(\mathrm{N} / \$)$ decreases, it becomes cheaper to import rice and vice versa. As the value of Naira appreciates, it strangles the availability of foreign exchange resulting in the reduction of the quantity of rice import. It is also noted, that within the period under consideration several exchange rate policies were implemented to reduce import and give buffer to the domestic economy. This finding agrees with the results of Ogundele (2007) and Aziz (2007).

In a similar manner, rice import showed significant negative and inelastic relationship with the country's nominal GDP. This means that, $1 \%$ change in the country's GDP will result to a less than $1 \%$ change in rice import demand in Nigeria. This result suggests the prevalence of high rate of rice smuggling along the country's international borders. This is because, the country has enunciated several tight trade; fiscal and monetary policies to check excessive rice import; but it seems these measures were not very effective or implemented adequately. The negative relationship between these variables could also be explained by the fact that, Nigeria's government has invested heavily on the development of the domestic rice sector and issues related to corruption. Several institutional frameworks, programmes and policies have been enunciated and implemented to upsurge rice production in the country. Hence, as GDP increases, more domestic investments are initiated to reduce capital flight which certainly has an inverse impact on rice import in the country. Chimobi and Ogbonna (2008); Igberi et al. (2012) and Aziz (2007) have reported similar result.

On the other hand, rice import has a positive and inelastic correlation with the political environment (i.e. the civilian regimes in Nigeria) in Nigeria. This means that, variation in the political environment in the country is more compared to changes in rice import demand. The causation relationship shows that, periods of civilian rules promoted rice import in Nigeria. This could be due to the sponginess of most trade and tariff policies in this era. The issue of corruption among government officials played a very important role in this relationship.

The coefficient of the external reserve in the long run model portrays significant positive and elastic relationship with the volume of rice import in Nigeria. It means that, a percentage change in rice import is more than equivalent change in external reserve. The causation relationship satisfies a priori expectation, as increase in the external reserves will increase incentives for rice importation. Nigeria over the years has always accumulate her surpluses inform of foreign reserve for future use and to enhance importation. This result represents the priority or preference of the government in term of investing her surpluses. The result is in consonance with the research reports of Nkang et al. (2006) and Igberi et al. (2012).

The result also revealed that, the rice import has significant positive elastic association with the liberalization policy period in Nigeria. The liberalization period in Nigeria was characterized by lessen trade restrictions inform of low tariffs and removal of quantity restriction in rice import. This period saw the establishment of institutions and policy frameworks that encourage importation. Privatization and commercialization were the key components of this era. Domestic agro raw materials were unable to sustain growth of agro based industries in the country. Shortages of domestic agro raw materials prompted many private firms to import raw material from the international markets. Lançon and Hélène (2007) have reported similar result for other developing countries.

Furthermore, a positive significant and elastic relationship existed between rice import demand and the net domestic credit to the Nigeria's economy. This means that, rice import demand expanded more than proportionate increase in the net domestic credit in the country. One possible reason for this result could be that, most portions of the credit were not channeled to the agricultural sector. Another suggestion that could help explained this phenomenon is that, large proportion of the credit was allocated to manufacturing sector to increase their absorptive capacity. This could increase raw material demand beyond domestic production.

\subsection{The Short Run Elasticity of Rice Import Demand Function in Nigeria}

The short run elasticity of rice import demand expresses the responsiveness of rice import demand to changes in factors that affect it. In this regards, the rice import demand has an elastic relationship with the domestic price of rice in the short run. This connotes that, $1 \%$ increase in the domestic price of rice will result to more than $1 \%$ increase in rice import. The causation relationship revealed negative significant association between rice import demand and domestic price of rice. This means that, as domestic price of rice decreases, demand for imported rice increases in Nigeria. This implies that domestic rice and exotic rice are complementary goods. Similarly, inelastic relationship exists between the rice import demand and the world price of rice in the short run. This implies that $10 \%$ increase in the world price of rice will result in more $10 \%$ increase in quantity of rice import in the short run. This confirms that rice is a normal good even in the short run period in Nigeria. Aziz (2007) noted similar result. 
Contrary to the above results, rice import has inelastic relationship with the external reserve and net credit to the country's economy in the short run. This result implies that, $1 \%$ change in these variables will result in a less than $1 \%$ change in rice import. However, the causation relationship between the variables shows that external reserve and net credit to the country's economy have positive significant relationship with rice import in Nigeria. Nkang (2006) has earlier reported similar result.

\section{Conclusion and Recommendations}

Rice import has been persistence in Nigeria. The country has enunciated several policies and programmes to upshot domestic rice production. Despite these lofty attempts by the government of Nigeria, rice import has continuously trended upward in recent years. The study has been able to identify the role of political and economic environments on rice import demand in Nigeria. The study revealed an exponential growth rate of about $15.97 \%$ from 1960 to 2014. The coefficient of time in the quadratic trend equation was negative which connotes that, over increase time the policy trust on domestic rice production paid up marginally in the country. The long run import demand function of rice had a negative significant relationship with the world price of rice, Industrial capacity utilization, nominal exchange rate, and the value of gross domestic production. The long run rice import demand also reacted positively to period of civilian rule, nominal value of external reserve, period of liberalization and the net volume of credit to the entire economy. The study discovered symmetric adjustment coefficient of $39.65 \%$ per annum in rice import demand in the country. In the short run, rice import had a significant negative and elastic relationship with the domestic and world price of rice; while it has significant positive inelastic association with external reserve and net credit to the economy.

Based on the findings, the following long run recommendations were proposed;

$>$ The federal government as a matter of policy should designed programmes and incentives to boost industrial capacity utilization in the country. Such policy should encourage backward integration among sectors in her economy.

> Markets determine nominal exchange rate should prevail in the economy, such that import demand will based on equilibrium market price and not subsidize ones.

$>$ The country should regulate its foreign reserve policy by setting a threshold, above which excess deposit should be plough back to the domestic economy inform of investments rather than support excessive importation.

$>$ Civilian regimes in Nigeria should strive to reduce corruption and ensured policy tight from conceptualization to implementation. This will remove some of incentives to rice import and encourage domestic production.

$>$ The liberalization policies in the country should be designed to followed quantitative policy objective in the long run especially in agricultural sector. Non-attainment of the target policy should inform policy makers to readdress such policy.

$>$ More credit should be allotted to the agricultural sector probably with regulated interest rate.

In the short run basis, the following recommendations are proposed:

$>$ Value addition to the domestic rice production will increase the competitiveness of the sub sector.

$>$ Credit to local farmers should be vigorously pursuit.

\section{References}

Akande, T. (2003). An Overview of Nigerian Rice Economy. Monography published by the Nigerian Institution of Social and Economic Research (NISER), Ibadan.

Aker, J., Steven, B., Vijaya, R., \& Peter, T. (2100). West African Experience with the World Rice Crisis, 2007-2008. CGD Working Paper 242. Washington, D.C.: Center for Global Development. Retrieved from http://www.cgdev.org/content/publications/detail/1424823

Akpan, S. B., Inimfon, V. P., \& Samuel, J. U. (2014). Analysis of Monthly Price Transmission of Local and Foreign Rice in Rural and Urban Markets in Akwa Ibom State, Nigeria (2005 to 2013). International Journal of Agriculture and Forestry, 4(1), 6-18.

Akpan, S. B., Ini-mfon, V., Glory, E., \& Daniel, E. (2012). Agricultural Productivity and Macro-Economic Variable Fluctuation in Nigeria. International Journal of Economics and Finance, 4(8), 114-125.

Aziz, N. (2013). Modelling Import Demand Function for a Developing Country: An Empirical Approach. 
Asian-African Journal of Economics and Econometrics, 13(1), 1-15.

Cadoni, P., \& Angelucci, F. (2013). Analysis of incentives and disincentives for Rice in Nigeria. Technical notes series, MAFAP, FAO, Rome.

Central Bank of Nigeria. (2015). Publication of the CBN. Retrieved 13 September, 2015 from http://www.cenbank.org/

Chimobi, O., \& Ogbonna, B. (2008). Estimating Aggregate Import-Demand Function In Nigeria: A Co-Integration Approach. Journal of Research in National Development, 6(1), 18-18. http://dx.doi.org/10.4314/jorind.v6i1.42411

Elliott, G., Rothenberg, T. J., \& Stock, J. H. (1996). Efficient tests for an autoregressive unit root. Econometrica, 64, 813-836. http://dx.doi.org/10.2307/2171846

Erhabor, P., \& Ojogho, O. (2011). Demand Analysis for Rice in Nigeria. Journal of Food Technology, 9(2), 66-74. http://dx.doi.org/10.3923/jftech.2011.66.74

Igberi, C. O., Nwibo, S. U., \& Odo, N. E. (2012). Analysis of import and export elasticity of agricultural products in Nigeria: 1975-2009. Journal of Science and Multidisciplinary Research, 4, 51-58.

Johansen, S. (1988). Statistical analysis of cointegration vectors. Journal of Economic Dynamics and Control, 12(2/3), 231-254. http://dx.doi.org/10.1016/0165-1889(88)90041-3

Johansen, S., \& Juselius, K. (1990). Maximum likelihood estimation and inference on cointegration-with applications to the demand for money. Oxford bulletin of Economicsand Statistics, 52(2), 169-210. http://dx.doi.org/10.1111/j.1468-0084.1990.mp52002003.x

Lançon, F., \& Hélène D. (2007). Rice imports in West Africa: trade regimes and food policy formulation. Poster prepared for presentation at the $106^{\text {th }}$ seminar of the EAAE Pro-poor development in low income countries: Food, agriculture, trade, and environment held at Montpellier, France.

Laurenceson, J., \& Chai, J. C. (2003). Financial Reform and Economic Development in China. Edward Elgar, Cheltenham. http://dx.doi.org/10.4337/9781843767190

Mayes, G. M. (1981). Applications of Econometrics. Prentice Hall, Inc.

National Population Commission Website. (n. d.). Retrieved 8 March, 2015 from http://www.population.gov.ng/

Nkang, N. M., Abang, S. O., Akpan, O. E., \& Edet, E. O. (2006). Rice production, imports and food security in Nigeria: An application of cointegration and error correction model. Journal of Food, Agriculture and Environment, 4(1), 86-90.

Obaniyi, K. S., Akangbe, J. A., Matanmi, B. M., \& Adesiji, G. B. (2014). Factors motivating incentives of farmers in rice Production training programmes A case study of Olam/US AID/ADP/First Bank Programme. Journal of Agricultural Research, 2(5), 74-81.

Ogundele, F. (2007). Trade liberalization and import demand for rice in Nigeria; A dynamic modeling. Journal of Economics and Rural Development, 16(1), 34-45.

\section{Copyrights}

Copyright for this article is retained by the author(s), with first publication rights granted to the journal.

This is an open-access article distributed under the terms and conditions of the Creative Commons Attribution license (http://creativecommons.org/licenses/by/3.0/). 